\title{
MARGARET FULLER'S EARLY POETRY: REFLECTION OF CULTURAL FEMINISM
}

Samaher Saeed Assi

Asst. Prof. AmalNassarFraq (PhD)

University of Baghdad, Baghdad, Iraq.

DOI: $10.37648 / \mathrm{ijrssh.v10i01.006}$

Received:29 $9^{\text {th }}$ September, 2019; Accepted:28th October, 2019; Published: $18^{\text {th }}$ November, 2019

\section{ABSTRACT}

This paper sheds light on Margaret Fuller's poems written in the early period. Margaret Fuller (1810-40) is one of the ground-breaking feminists that struggled for women's rights in the United States in the nineteenth century. Fuller's early poetry has the seeds of cultural feminism which aims at empowering women and treating them as distinctive individuals. Fuller —as a feminist poet in the early period-concentrates on these important principles of cultural feminism. Most importantly, she puts emphasis on the characteristics of women's potentials which sometimes surpass men's; in other words, Fuller's feminist thought asserts the concept of matriarchy through her poems to her friend Anna Barker and some other poems that deal with gender, using certain language and symbolism.

Keywords: cultural feminism, antebellum women, patriarchy, female empowerment, flower language, gender roles.

\section{INTRODUCTION}

The largest part of readers think of Margaret Fuller as a book reviewer, essayist and travel writer in spite of the fact that she published a number of her poems in the Dial, the mouthpiece of the literary movement, Transcendentalism, in addition to the emergence of some of her remarkable poems in her influential books, Woman in the Nineteenth Century (1845) and Summer on the Lakes, of 1843 (1844) ("Steele, Freeing"137). Joan R. Wary ascribes the reason of not mentioning Fuller as a poet to her Tribune correspondences and her prose that overwhelm her poetry (75).

In short, if someone traces scholarly studies of Fuller, s/he can notice that Fuller's poetry does not get much of critical significance. Fuller is remembered as a critical theorist only in her prose writings in feminism. However, Fuller wrote a number of poems on feminist themes that deserve to be taken into consideration in the early and mature period. In other words, Fuller skillfully and used her poetry as a means (along with prose writing) to defend against inequality between gendersthough she has sunk into oblivion as a poet.

Basically, Fuller's poetry is confessional, autobiographical. Jeffery Steele notices that Fuller's poems include biographical facts that are necessary for a comprehensive understanding of the development of her emotion and her intellect as a writer ("Freeing" 137) and as a pioneering feminist. Steele further states that sometimes, her poems are the best, if not the only, source in understanding the nature of her relationship with Anna Barker (18040-1900), the quality of her 1840-41 spiritual crisis, the emotional aftermath of her relationship with Sam Ward (1817-1907), and her use of archetypal goddess imagery (137), among other aspects that are crucial in identifying Fuller as a feminist poet.

Fuller's poetry in the early period gradually takes various turns, perhaps; therefore, it should be divided into three categories in accordance with its 
feminist themes in order to make it more transparent and more intelligible to readers.

\section{FRIENDSHIP POEMS TO ANNA BARKER}

In the early period of her poetry, Fuller wrote a number of poems that have the seeds of cultural feminism where she confirms women's potentials and tries to create a distinctive women's culture. Her poems dedicated to Anna Barker rank the foremost among her other early poems. Fuller's poems to Barker in 1835-37 denote strongly autobiographical element in which Fuller addresses real people (Wayne, Encyclopedia 207).

What really makes Fuller write poetry to her friend Barker, Tiffany Wayne reasons, is that in Fuller's heart,Barker has a special place. She is one of the young protégés who surround Fuller during Boston Conversations but Fuller's relationship with Barker is a more profound one. Barker is "my heart's sister and my fancy's love", Fuller once declared. Further, in her 1842 journal, Fuller describes Barker, saying that: "Her face was always gleaming before me, her voice was echoing in my ear, all poetic thoughts clustered round the dear image". Megan Marshall clarifies that Fuller tries to show that their love is "the same love we shall feel when we are angels" (Wayne, Encyclopedia 307,Marshall 61).

The most noticeable feature in this group of poems is that there is insistence on the idea that experiencing nature becomes most expressive when it is shared with another person. Though such feeling is common in the poetry of the English Romantics, as in William Wordsworth's "Tis a Beauteous Evening, Calm and Free" (1802), it is in sharp contrast with the high quality situated on isolated moments of reverie in the works of Fuller's male contemporaries, Emerson and Thoreau. Particularly, in contrast to Emerson, all the time, Fuller insists in her career that the experience becomes more meaningful when it is shared with a friend (139).

It seems preferable for Fuller that such friend should be a female with whom she can attain a utopian female friendship - also, as a cultural feminist, Fuller celebrates identifying women with nature in her poetry, trying to create a separate women's culture.
Speaking of friends, Fuller confirms in her "Autobiographical Romance" that "these not only know themselves more, but are more for having met, and regions of their bloom and song." This important ideafeature of American female writings in the nineteenth century in contrast to men's writing - may find its earliest formulation in Fuller's 1835 sonnet " To.Sunset, After leaving New York August 1835" (Steele, "Freeing" 137).

The title of this poem, as well as the other poems to Barker, sets a mold for the pattern "To ...." (A pattern that characterizes twelve of Fuller's poems) which gives much of her poetry an apostrophic and epistolary feature (Steele, "Freeing" 137), which is mostly used between friends. In a descriptive, rich language, the poem begins describing a beautiful landscape which takes on meaning as it is shared with a friend:

That gorgeous eve! Its wealth of Sylvain dye!

Say, are they living in thy fancy yet!

Can age, on asking care bid us forget

The magic wonders of that sunset sky?

$\cdot$.

And sea and air in one blue circlet blending,

While a swift-scudding sail its romance gave,

Unto Night's secret realms speeding afar,

And bearing human hearts from us away,

Ere flashing sympathies could bid them say

If they like us, lure for the evening star, $-(1-4,7-12)$ 
In the closing lines, the poet clinches her argument with the confirmation: "All this we both could see, together feel, - / Since then, no more alone at Nature's shrine I kneel"(13-14) ("Freeing" 137, 139). Her aim here is to find a new female culture that is different from the contemporary prevalent concepts held by traditional patriarchal system.

In the fall of 1835, Fuller-Barker friendship takes on another image and terms as well. Fuller, Jeffery Steele argues, begins constructing the image of a female savior in her imperfect, unpublished sonnet "To the Same. A Feverish Vision," which is the most important of her poems to Barker, as Steele asserts. The pattern of a distressed woman " reaching up to a star like female savior" is one of the most typical paradigm in Fuller's writings which begins offering her a means to get rid of her pains resulted from the harmful effects of her father's rigorous educational system - which is associated with discomfiting Roman principles in her "Autobiographical Romance" ("Freeing" 139, Transfiguring 36).

This poem begins depicting a more distressed, unstable aspect of Fuller-Barker relationship. It describes how the speaker ends a day of a "wearying, wasting pain" with a fearful nightmare of drowning in a ditch of blood; "a powerful symbol of female, blood" recurs in Fuller's nightmares (Steele, "Margaret" 163, Wayne, Encyclopedia 307):

After a day of wearying, wasting pain,

At last my aching eyes I think to close;-

Hoping to win some moments of repose,

Though I must wake to suffering again.

But what delirious horrors haunt my brain!

In a deep ghastly pit, bound down I lie,-

About me flows a stream of crimson dye,

Amid its burning waves I strive in vain ;(1-6)

Then, Fuller shows how a godlike female (the figure of Anna Barker) appears to save her from that nightmare.
For Fuller,at this point, one could notice that the association between self-fulfillment and friendship is "dramatized within divine plane"(Ellison 249):
Upward I stretch my arms,- - aloud I cry
In frantic anguish,-_"raise me, or I die!
When with soft eyes, beaming the tenderest love,
I see thy dear face, Anna! far above,- By magnet drawn up to thee I seem, And for some moments was dispelled the fever's frightful dream! - (L 9- 14)

To this poem Fuller links a moment in one of her dreams in which "a sweet female form" rescues her from an unbearable headache: "The feeling I had was the same when Anna in the fever drew me up out of the pit of blood. It is the true feeling of feminine influence . ... As I have masculine traits, I am naturally often relieved by the women in my imaginary distresses." In her personal mythology, Fuller is elevated by an idealized image of "feminine influence" from a bloody realm of psychological and physical sufferings to an area of transcendence. Fuller's poems as well as her journals show that the images of Anna Barker served as an early paradigm for this kind of a transcendent female figure(Steele, Transfiguring 36).

In a number of versions of Fuller's recurring nightmare, the ditch of blood echoes a scene Fuller depicts as having "read in her Virgil"; Aeneas' story of the battle of Troy wherein Aeneas is rescued from carnage of Troy by virtue of a vision of the goddess Aphrodite (Venus), his mother, who " came before my eyes," says Aeneas, "in pure radiance gleaming through the night". Fuller's rescue from the ditch of blood by Barker in her dream is like Aeneas's rescue from the carnage of Troy by a goddess. So, Fuller's masculine side (when identified with Aeneas) cannot rescue her; just like Aeneas who has to be saved from unruly passion, his desire for revenge, by the goddess, Fuller needs to be rescued from her pains by "a maternalized female power" linked to her confidante. That is, the common gender narrative of "feminine influence" is reversed by Fuller; she constructs a psychological 
narrative in which an imaginary female who is similar to Anna Barker saves Fuller's "endangered 'masculine' persona" (Steele, "Margaret" 164, Transfiguring 37).

In another striking poem entitled "To A. H. B.1 On our meeting in my return from New York to Boston, August 1835" (1836), Fuller puts emphasis on maintaining her friendship with Barker, expressing her fear that "the haunts of men" threaten her intimate friendship, "Oh could we on the waves have lingered them, $\backslash$ Or in that bark, together born away" (9-10).

Celebrating the beauty and the strength of a female friendship, the poet imagines that she and her friend escape the ills of the world to a safe expressive refuge, where they both live peacefully together removed from such haunts that threaten their friendship (Wayne, Encyclopedia 307): " Have sought some isle far from the haunts of men, / Ills left behind which cloud the social day, / What grief I had escaped yet left untried"(10-12).

One could assume that in the light of the conventional oppressive practices set up by maledominated society, by "ills" Fuller alludes to the suppression of women and the patriarchal restrictions imposed on women. Accordingly, Fuller suggests getting rid of these restrictions, of such societies by escaping to an ideal place, a community led by females where females can develop their identities apart from the suppressive authority of males influence to find freedom, justice and peace-Fuller in her successful Boston Conversations steps toward affirming the main theme of this poem. She proposes and sees a new image of the "perfect rest" through the lenses of matriarchy.

And thou, although for thee my loving

heart

Would gladly some Elysium set apart,

From treachery's pestilence, and passion's strife,

untroubled life,
Where though might'st lead a pure ,

\author{
Sustained and fostered by hearts like \\ thy own,
}

The conflicts which thy friend must brave, unknown, -

Yet I feel deeply, that it may be best

For thee as me, that fire the gold should test,

And God's good time we should know perfect rest! (16-24)

Later on, in her masterpiece Women in the Nineteenth Century, Fuller develops the idea of matriarchy(albeit in a confrontational mood) in which she urges women to form their independent identities apart from men and thus they, Fuller metaphorically states, would be capable of turning the worthless things to precious things:

\begin{abstract}
Women must leave off asking them [men] and being influenced by them, but retire within themselves, and explore the groundwork of life till they find their peculiar secret. Then, when they come forth again, renovated and baptized, they will know how to turn all dross to gold. (108)
\end{abstract}

Jeffery Steele notices that in this poem, whilethis shift from escaping to confronting the ills of the world is typical of Fuller's later writings, "so too is the high premium placed upon friendship as a source of emotional strength" ("Freeing" 140).

Furthermore, Fuller's poems to Barker seem to have a sense of spiritual insight that aims at attaining utopian friendship (mostly in accordance with Emerson's theory of self- reliance but in a modified version), a female friendship through which women can find space to develop their identities and open-ended possibilities apart from men's shackles and their emotionally negative influences. 
In fact, Fuller appreciably revised Emerson's principle of self- reliance wherein Emerson puts emphasis on masculine discourse in his contentions in his seminal book Nature (1836). The latter supports the powerful expansion of a masculine dominion based partially upon the model of Julius Caesar. But Fuller, as a woman writer in antebellum America, is not able to accept Roman character as an example without a consequent alienation that alienates her from the maternal side of her identity. She further finds that this imperial Roman discourse ignores the needs of women (Steele, The Essential xvi).

Specifically, Emerson states that the development of the psyche of people is determined by intuition and expression of masculine power. In response, Fuller creates a new model of personal autonomy and female empowerment (Steele, Transfiguring 50), bearing in her mind the question of the differences between genders.

\section{FLOWERS POEMS}

Fuller wrote in her early poetry another group of poems that are as significant as her earlier group to Anna, employing different technique in which she uses flowers as a rich symbolic vocabulary of female potential. She uses the language of flowers as one of the discursive strategies in some of her early poems.

Nowadays, only some readers remember the extent to which the nineteenth-century America thrilled in a language of flowers. Sometimes, one might linger over one of flower poems by Emily Dickenson (183086 ), such as her brief lyric in 1839 , which opens with: "A Bee his burnished Carriage / Drove boldly to a Rose-". But few have doubts about Dickenson's capability of using flower imagery to construct psychological as well as social allegories echoed a prevalent interest in the association between flowers and various sentiments ("Freeing" 145).

In the general lexicons of the period, like Sarah Hale's Flora Interpreter (1833) and Catherine H. Waterman's Flora's Lexicon (1854) each type of flower was matched with a different sentiment or sense. The dissimilarity of interpretations between books suggests that the language of flowers was not "a fixed code but a style of signification that was easily adapted to the needs of different individuals". This strategy was dominant in the works of women writers in the nineteenth century because the floral lexicon made them able to symbolize and analyze varieties of feelings that were not easily approached through using ordinary language (Marino 145).

Although the association between women and flowers has existed in the Bible, folk tales, mythology and literature for centuries, the cultural principles of women as domestic individuals started in the nineteenth century. It is noted that flowers were in fact seen as the most suitable aspects of nature to represent women, or to "interact with them reflecting as they certain stereotypical qualities of female being: smallness of stature, frailty of mind and body and importance of beauty. "The association of women with flowers is unsurprising in a culture interested in treating a limiting role for women by assigning them the fundamental virtues of religiousness, purity, domesticity and submission (8-7). As Barbra Walter's puts it in her "Cult of True Womanhood: 1820-1860" (1966):

\section{She [woman] was expected to have a special affinity for flowers. To the editors of The Lady's Token "A Woman never appears more truly in her sphere, than when she divides her time between her domestic avocations and the culture of flowers." (165)}

Accordingly, women like Fuller retrieve the language of flowers to make it a liberating language that can empower women in expressing themselves. Fuller took the conventional language which many women embraced in a conservative society and changed it into an alternative language of resistance. For, Fuller, flowers are more the physical shape of ideas than living objects. She implies in her writing that flowers can stand for "feminist possibility" and they can also be the representative voice of women. This representation expresses grace and strength which are the best qualities of womanhood. The language of flowers for Fuller "provides a conventional, rhetorically safe, and socially acceptable communication to embed in her writing a 
type of early feminist discourse" (Kopcik-Rhyner 8-9, 23).

Originally, Thomas Wentworth Higginson notices that Fuller inherited her fascination in flowers from her mother who divided her time between her children and her garden, practicing a type of "double domesticity". In 1844, Fuller told William Henry Channing in a letter (Marino 3):

You often tell me what to do when you are gone; if you survive me, will you not collect my little flower pieces, even the insignificant ones? I feel as if from mother I had received a connection with the flowers; she has the love, I the interpretation. My writing about them are no fancies, but whispers from themselves. (Higginson 97)

In "The Columbines" (1839), Fuller presents a sort of remedy for the deep-rooted problem in the American society, the cultural injustice of women-as women were treated as inferior to men. Fuller sent this poem to her confidant Caroline Sturgis on October 1839, using the wild columbine (the symbol of desertion in Sarah Hale's volume) as a developed new symbol. Specifically, Fuller creates a new image from the columbine flower to be a symbol of grand independence, of self- reliance and resistance to the principles of patriarchal society which force women to get married at an early age and consequently causing in reducing their chances of making self-realization (Marino 4, Maas 185).

And the importance of self-reliance is emphasized when the poet describes the columbine's life. Christel-Maria Maas argues that Fuller considers the columbine - that she calls "prophetic flower" — as one of the strongest creatures as it counts on itself. The columbine, as well as the renewed flower-like woman the poet promoted, is portrayed as an independent figure in the second part of "The Columbines": "Yet has my flowret's life a charm more rare / Than those admiring crowds esteem so fair, / Self-nurtured, self-sustaining, self-approved" ( 11-13 ). This flower can survive and thrive in every soil and every circumstance; and not necessarily should be the comfortable and domesticated, though limited, space of the garden. The way the columbine lives in loneliness does not show a negative aspect, but it refers to a positive condition that it chooses for itself since it reflects a happy state of autonomy (Maas 185, Marino 5):

Not even by the forest trees beloved

As are her sisters of the spring, she dies

Nor to the guardian stars lifts up her eyes,

But droops her graceful head upon her breast,

Nor asks the wild-bird's requiem to her nest,

By her own heart sustained, of her own soul possessed. (14-19)

In the third part of her poem, Fuller tries to give her favorite flower, the columbine, especial importance by counting the merits of some other flowers which stand for prevalent domesticity:

Learn of the Clematis domestic love,

Religious beauty in the Lily

see,

Learn from the Rose how rapture's pulses rove,

Learn from
the Heliotrope
fidelity,
From autumn
flowers let hope and
faith be known, (26-
30)

That is, Fuller hopefully recommends women, encouraging them to learn not just the conventional domestic values associated with flowers (Marino 5). At 
the end of the day, in her view, women should learn to be more independent; they should be as strong as this wild flower so that they can get their rights in their oppressive society. She implicitly advocates antebellum woman to be a" new woman" rather than a "true woman":

Learn from the columbine to live alone,

To deck whatever spot the Fates provides

With graces worthy of the garden's pride,

And to deserve each gift that is denied. (31-34)

Obviously, Fuller uses the language of flowers differently by changing its prevalent, traditional association with true womanhood. The message of this poem greatly informs Fuller's two flower sketches, "Yuca Filmentosa" and "The Magnolia of Lake Pontchatrain" she published in two separate issues of The Dial in the same period in which she uses a flower as an empowering icon for the strength of women. Examining situations of female spirituality beyond the boundary of patriarchal monotheism of Fuller's culture, these works make clear a region of female myth that begins to appear in her other poem, "In a fair garden" in 1839 (Marino 4-5, Kopcik-Rhyner 10, Steele "Freeing" 146).

Actually, the year 1839 is a crucial aspect in making an alteration in Fuller's imaginative development due to a number of facts and events in her public and private life, i.e. professionally, her Boston Conversation, her deeper involvement with Transcendentalism, a connection which would result in her assuming the editorship of the Dial. And personally, while she keeps her friendship with Anna Barker, her other friendship with Sam Ward deepened into a romance which would be crushed by the news of Anna and Ward's engagement (Steele, "Freeing" 146).

The consequences of Fuller's emotional shock resonate throughout Fuller's writing over the next five years. Nevertheless, during the fall of 1839 and the summer of 1840, Fuller regains her strength quickly. Although she enters a period of rapture that struck Emerson, Fuller grants her sincere congratulations to Ward and Barker and celebrates with their other friends the newly Barker-Ward love affair. Referring to Ward on his birthday, Fuller wrote this poem sending Emerson what she calls "a chapter out of my poetical journal" wherein "all the verses even the translations bear references to Anna, W. and myself" (145).

In this poem, which has autobiographical signification, Fuller chooses a pastoral, remote place, using three beautiful flowers: the Rose, the Dalia and the heliotrope. Each flower has a significant meaning. The Rose stands for Fuller and the Dalia stands for Barker. The heliotrope, Joan Von Mehren clarifies, is Fuller's favorite flower and signifies "distinguished merit" and a "delicate sensibility", as she stated in a letter to Emerson after a few months of writing this poem. Barker and Ward, Mehren also says, are portrayed as a Dalia and a nightingale, enjoying the pleasures of life while nearby grew a floweret (Fuller) that seeks an ampler urn (112).

Commenting on her complex emotional situation as well as of her friends', the poem starts moving in that direction as it contrasts the Dalia's conventional beauty with the situation of the other two flowers, the rose and the heliotrope (Steele, "Freeing" 146).

In a fair garden in a distant land Where autumn skies the softest blue outspread

A lovely crimson Dahlia reared her head,

To drink the lustre of the season's prime;

And drink she did until her cup overflowed

With ruby redder than the sunset cloud

Near to her root she saw the fairest rose

That ever oped her soul to sun and wind. 
Upon the other side, nearer the ground,

A pale floweret on a slender stem,

That cast so exquisite a fragrance round

As seemed the minute blossom to contemn, $(1-8,15-18)$

The main action involves a moment of emotional dislocation. Fuller states how "The Rose" turns from the love of Dahlia and nightingale (Barker and Ward) toward an identification of "the love-note of the Heliotropes." Though the heliotrope is associated traditionally with the sun, Fuller places this flower in order that its "exquisite" scent only becomes noticeable when the evening approaches. This dislocation imposes a contrast between the sun and a figure (the moon) that remains implicit in this mystical poem but who becomes prominent in Fuller's works over the next two years. Put a different manner, it suggests a shift in the center of power. That is, a turning away from masculine toward feminine (Steele, "Freeing" 146, Mehren 112).

By the evening, the heliotrope shows "its secret soul" that captivates the Rose. The Rose forgets the Dalia and nightingale to turn toward this disclosure of the "secret soul" as a cause of "deeper joy". Forsaking the formerly fascinating image of heterosexual love, and "all the familiar rewards of masculine attention," the poet adjusts herself to a "feminized emotional center", to "the love-note of the Heliotrope" that assures a spiritual awareness connected to the moon and the night (Steele, "Freeing" 146).

When at the charming of the evening dew,

The floweret could its secret soul disclose,

By that revealing touched, the queenly Rose

Forgot them both a deeper joy to hope,

And list the love-note of the Heliotrope. (26-30)

At this point, Fuller uses the Rose and the Heliotrope to show two aspects of herself, a technique that structures her romantic essay "The Magnolia of Lake Pontchartrain". The "Rose" is a symbol of her social side that once amused in the attention of Ward and Anna Barker, whereas the Heliotrope evokes the mystical aspect that starts to emerge after the trauma of their rejection to her. Sublimating the image of love into a "divine love", Fuller begins to submit the conventional happiness of love stories and marriage for a harder, yet more profound, direction-which evoked by the disclosure of a "deeper joy" (Steele "Freeing" 147).

\section{GENDER ROLES POEMS}

The new phase of sublimity and divinity that shapes love stories and marriages in Fuller's writings has turned out to be a state of "rapture" that Fuller enters in the fall and winter of 1839. Fuller clarifies the extent to which this development takes place in unpublished journals that year. For example, in December, describing her state of mind during the preceding autumn, Fuller states: "Yet O it seems almost no mortal before me can know such a rapture as mine in the pine wood. Alas that I cannot paint it, only tell the feeling." And on October 1840, due to her loss of Anna Barker and Sam Ward and their marriage which coincides with nearly the anniversary of her father's death, Fuller enters a period of "ecstatic solitude" which she later describes as "the era of illumination in my mental life" (Steele "Freeing" 147-48, "Margaret" 164). This era results in developing Fuller's feminist thought and, in tackling the question of gender roles.

Fuller is, in fact, driven by her sad circumstances into "a deep mystical seclusion" in 1841, finding herself compelled to embody a situation of selfreliance, to "attune the self to its inner spiritual resources". This vision ofself-reliance is tempered with a discourse upon the need of friendship in Fuller's letters, poetry and other writings, a continuation of the theme of her poems to Barker. But it is the period of enforced solitude that teaches Fuller "the value of beingfor herself and being-with-others" at the same time. Both sides are crucial elements of Fuller's mature thought: the political activism of Woman in the Nineteenth Century is unthinkable without appreciating both of the need of woman for individual selfdevelopment and an understanding of others' necessary agency in that maturation process ("Freeing" 147, Encyclopedia 164). 
Fuller, Tiffany K. Wayne points out, "is the first feminist in the United States to systematically apply romantic or cultural idea of individualism, with its emphasis on the self-development, to women (WomanThinking 45). Fuller deals with woman's question in terms of attributing her characteristics that make her reach self-fulfillment because woman is "the other half of the same thought, the other chamber of the heart of life" (Fuller 13).

From this point on, Fuller's poetry begins moving toward the situation in which she most directly tackles the responsibilities and demands of solitude, the basis of her own theory of self-reliance ("Freeing" 148,"Margaret" 164), which affirms women's individuality and enables them to take on new roles that have been oppressively limited to men according to the traditional masculine values.

At the heart of Fuller's personal crisis on the first of July1841, New Year's Day, Fuller wrote, most likely, the most remarkable of all her poems, a onehundred-and-thirty-six line, unpublished "River of beauty flowing through the life", which was published later on in 1844. It is a rhapsodic and psychological allegory wherein Fuller traces the course of her life's "river of beauty" that it had once smoothly flowed through "plain and vale". But now it "plunged ... astonished" down a "chasm in the earth" through a "wild cleft" into, a region Fuller depicts as (Steele, "Margaret" 164),

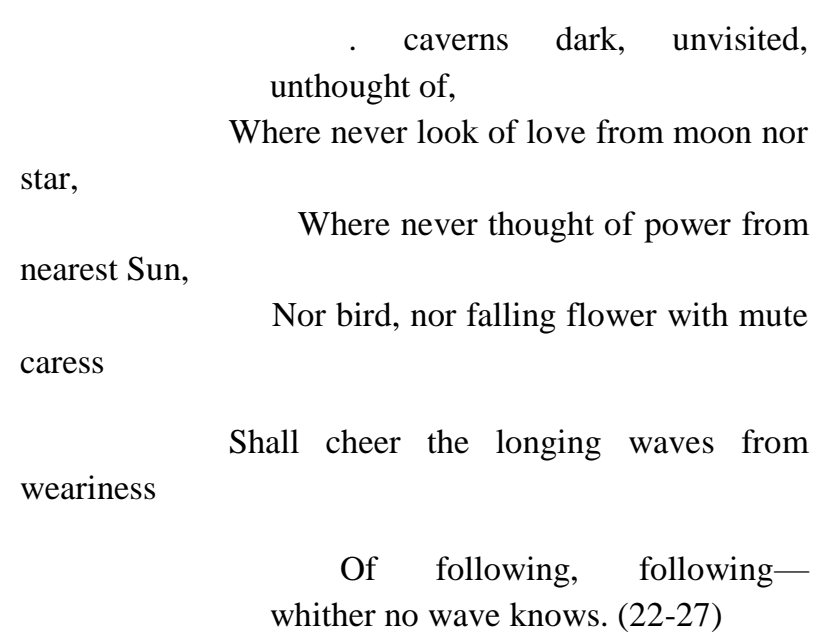

The poem displays a journey that takes place inside the poet herself. The cave stands for the unconscious of the poet. In the cave, the speaker enters a hall of echoes.

In the hall, the poet resolves to "dress the hall where they abide / With diamond sheen which asks not to be seen" (39-40). But all of a sudden, the "treasure of accreting insight" lights up the "dim grotto" with an identification of solitude: "The inmost powers a strange convulsion cause / And give the glorious secrets of sad love" (43-44) (Steele "Margaret" 164).

Then, the poem describes a landscape that looks like heaven where distinguished figures dwell in: "pilgrim angels" and Melodia, a romantic sufferer who is a mask of Fuller herself:

The pilgrim angels wandered on the plain

Long, long had most been absent from their home,

All suffered, and all strove for their return,

Melodia suffered most, much would have striven,

Had but her way been clear. (50-54)

Although an "endless wishing sweetness" flowed through her, Melodia seeks a "guide" to have that "sweetness harmonized". Manifesting the rapture that Fuller experienced during the summer of 1840, Melodia is overwhelmed by her solitude. Melodia is currently wandering, weeping, through a grove wherein no one hears her song. Portraying the pain and the ecstasy of her spiritual crisis of 1840-41, Fuller uses the figure of Melodia to make a diagnosis of her solitude besides dramatizing her consequent illumination. This kind of emotional valence is captured precisely when Melodia — overwhelmed by loneliness - sings to herself and is amazed by the appearance of a familiar figure (Steele "Margaret" 164):

When lo! a note sent back, vibration felt, 


\author{
Startled her soul to sudden \\ revelation,
}

And near her stood her angel and her friend,

Receptive, bounteous, radiant, and profound. (77-80)

Reminiscent of Ward, who abandoned his art and worked in trade to marry Barker, this figure recalls the pain of Fuller's emotional loss but at the same time her success in compensation in artistic creation. For here, Melodia whose name stands for love and music, is a sculptor and her "keen voice" has once the ability to release a masculine figure "from the rock" (Mass 162, Steele, "Margaret" 164), that is, women are able to change their state of loss to a state of success and triumph because of their essential qualities that make them positively different from men.

But Melodia this time draws this masculine figure forth from his captivity:

But now the hour had come;-

And, through the skilful wounds and splintering blows

Which Nature uses most, loving the most,

Slowly he had come forth, of godlike mould.

The Paria, from Paros' whiteness named

Sepulchral whiteness of the holiest tomb. (90-95)

A deep image of artistic creation - the hewing of the marble that is valued by Fuller-this reminiscent passage suggests as well the appearance of a profoundly buried complex to the scope of awareness. From the psyche's depths, Fuller depicts an image of the figure of the muse - that bears Samuel Ward's lineaments, transfigured now. On the other hand, a more deeply buried image comes into light as well. Rising from its "cradle tomb," the figure of Paros bears an instantly recognizable psychological echo - the sketches of Ward $\backslash$ the Muse resolve also into the shape of Timothy Fuller, Fuller's dead father (Steele, "Freeing" 150).
In other words, the female solitary figure, Melodia, in "River of beauty" has unique female traits - as for example her "keen voice" — that enable her to call forth masculine figure, Paros, from incarceration. Once again, Fuller here affirms female possibilities and superior virtues that make female as creative and effectual as male, and even more, in her society. And in her so doing, Fuller tries to depolarize the conventional gender roles in her masculinized American society in the nineteenth century.

The double echo of losing her friends Anna Barker and Sam Ward, along with her self-conscious mourning at the incomprehensible psychological changes Fuller was going through, provoked her toward moments of narration that echoed the process of grief. During this period in several letters, for example, Fuller compares herself to the Virgin in her mourning. References to the tomb, death and funeral monuments appear recurrently in Fuller's writings between 1839 and 1844. By the time she writes "The Great Lawsuit", Fuller can find herself, in her public writing, with female figures that are able to break "the spell of the grave". But Fuller's poetry in 1844 shows that this process of mourning was not determined until she completes her book Woman in the Nineteenth Century at the end of that year (Steele, "Freeing" 151).

This poem shows that resolution by evoking a moment of Melodia and Paria's ecstatic unity. They are both "united" in "One marble gleam, one short and lovely note" (101-02). There is a moment of harmony that makes life flow through Melodia, it resolves the two discords that divide the poet's imaginative life (Maas 162, Steele, "Margaret" 164):

moment full

$$
\text { Birds drawn back to the nest, one }
$$

They felt the pulse of the creative heart,

And were the key-note of Concordia,

They lived the multiple of Unity,

Revolved, the all-embracing Sun and Moon,

Shed forth in that one look of mutual love

And stars, flowers, rivers, Angels, Gods and Thoughts, 
And brooding, trembling, hovered into life

Such was the smile of God which these two angels meant,

The fullest utterance One has ever made,

The much that calls for more, the light of final shade. (109-19)

Fuller was fond of making a balance between the antinomies dividing her being: Mother and father, garden and library, nun and amazon, sun and moon, Melodia and Paria and Minerva and Muse; in Women in the Nineteenth Century, these terms thrive as poles of a psychological process, driving Fuller to her dream of harmony, the "sacred marriage" she identifies eventually in a poem carries that title (Steele, "Freeing" 151).

In other words, the cave here may refer to the unconscious of the poet where two figures stand for two poles within the poet, or inside her consciousness: aestheticism and intellectuality, the Greek and the Roman values. And the moment of harmony here could be an echo of Fuller's desire to do balance between both parties (emphasis added).

Fuller's unique sense of vocation is caused by the evocative awareness of herself as a separated being, trapped in the middle of two worlds: "the sweet domestic world of nineteenth-century mothers and the aggressive intellectual world of the fathers". Melodia and Paria's union seems to present a kind of balance in this quest ("Margaret" 165).

However, this moment of harmony does not succeed, partly because it does not present a permanent alternative to the traditional roles held by lovers from male and female, Melodia exhibits briefly an artistic strength - the capacity to call forth her muse, Paria, from his imprisonment. In that moment, "Speech wedded silence, Death life crowning crowned" (124), but the moment passes; each figure returns to his previous state; Melodia returns to her world of solitude and Paria returns to "the secret caves". Fuller's ecstasy ends with a lament, as Melodia reaches ultimately to a disappointed end ("Freeing" 151, "Margaret" 165):

But she, Melodia!
How can she wait, a voice, which was a life?

Oh reassure Eternal Harmony, This wandering vestal of herself bereft,

And veil in prayers the breast without a heart,

And bind with truth the wound that truth has made, and clam in faithful calm death the broken life of love. (130- 36)

Despite the fact that the moment of harmony ends up with the failure of the union between Melodia and Paria, there is a clear invitation for adopting a new culture of harmony in which Fuller attempts to accomplish balance between the two unequalled, unbalanced worlds of both female and male in antebellum American society.

By 1843, Fuller could control the idea of loss within poetic framework which made more stable models of personal transformation more possible.She turned to myths and began using mythical figures in her poetry so that,Fritz Fleischmann asserts, she could destabilize "cultural formations that are posing as natural"(29).In Margaret Fuller and Myth, Robert D. Richardson argues that Fuller is more interested in the personages of the myth than its setting or the plot; consequently, she utilizes a variety of figures in serving her as a form of symbolism, a version of typology (172).

Fuller wrote her first remarkable sonnet in "The Great Lawsuit" whichopens with mentioning the myth of Orphus, imagining the poet's role to be "excavation of buried powers", (Steele, "Margaret" $165)$

Each must to the depths descend, For only thus the Poet can be wise,

Must make the sad Persephone his friend.

And buried love to second life arise; .... (1-4)

Robert D. Richardson points out that for Fuller, Orpheus is an image of the perfect man and lawgiver, not only of the poet but the "Idea of Man," as she prefers to put it. 
"A better comment could not be made on what is required to perfect Man, and place him in that superior position for which he was designed, than by the interpretation of Bacon upon the legends of the Siren coast" (181).

Fuller then carries on changing and remolding that male model, leaving the earlier Greek model behind with her own version of German idealism into a type of man toward which one should act. She strikingly declares, asserting that (Richardson 181, Steele, "Margaret" 165):

\begin{abstract}
Meanwhile not a few believe, and men themselves have expressed the opinion, that the time is come when Eurydice is to call for an Orpheus, rather than Orpheus for Eurydice; that the idea of Man, however imperfectly brought out, has been far more so than that of Woman; that she, the other half of the same thought, the other chamber of the heart of life, needs now take her turn. (Woman 13)
\end{abstract}

Journeying into the underworld after his wife's death, Orpheus displays a bravado which is celebrated by male Romantics. However, in Fuller's hands, this personage takes on an irony and complexity missing in the more dedicatory allusions of males in Fuller's time (Steele, "Margaret" 165).

Furthermore, the way Fuller turns the tale on us is what gives Fuller's modification novelty and freshness. In the original myth of Orpheus, Death told Orpheus that he could rescue his wife, Eurydice, on condition that he did not look back until after they both came back to the upper world, the world of living. Yet, he yields to curiosity, looking back to lose Eurydice for the second time. Fuller, interpreting Orpheus as a representation of men's distrust in women, suggests that Orpheus failed in trusting his woman enough to lift her up to his level. Instead, he abandons her, leaving her in the underworld of a half completed psychological process. For Fuller, man has not been successful in rescuing woman and it is time to reverse the performance and allow woman to save man and raise him to a higher degree of self-realization (Steele, "Margaret" 165, Richardson 179).

As Fuller understood well from her study of Ovid's Metamorphoses, the call of Orpheus and the finding of his poetic career were caused by Eurydice's loss to Hades. In her "Autobiographical Romance", Fuller states that "Ovid gave me not Rome, nor himself, but a view into the enchanted gardens of the Greek mythology. This bath ... I have been following ever since." Surrounded by silence as well as objectified by masculine discourses, Eurydice became the cause of male imaginative production. In revising the equation, Fuller disturbs one of the dominant traditions of male discourse (Steele, "Margaret" 165).

In position of a submissive and silent Eurydice, the muse of Orpheus that caused an eternal series of mourning, she envisions a female agent who runs away from an economy of sorrow wherein woman stays the most suggestive signifier. By calling Orpheus, Eurydice inducts a new different vocation, where woman finds herself a role as the agent of producing art and not merely its object and thus the role of the savior who would save man. By giving woman an active power, this work revolutionizes the common nineteenth-century myth of female influence; it also foreshadows the role Fuller herself embraced in her most essential poems (Maas 151, Steele, "Margaret" 165).

This means that Fuller presents a new image of woman to the reader in which woman is put in the position of action, activity and responsibility of new kind and in her doing so, she indeed reverses the traditional, prevalent formula that identifies the roles of woman and man in the American society in the nineteenth century: remarkably, she reshapes nineteenth-century gender roles.

However, according to Fuller, Eurydice must cope with both Orpheus's absence as well as her own grief, the death she holds within before she is able to call Orpheus. Fuller suggests that Eurydice can begin her long journey back to life only by facing the part of her being that has been recently paralyzed and killed as 
well. Mourning herself, she retrieves that trapped part with Orpheus in the underworld. In Fuller's hands, this modified narrative of mourning tackles a political dimension. The tone of Eurydice's grief stays; however, it is subjected to increasing belief that through selftransformation, woman's pain can be overcome (Steele, "Margaret" 165).

Here, one could consider that in mythmaking, Fuller is to some extent comparable to the English romantic poet Percy Bysshe Shelley (1792-1822), who is known as one of the experts in mythmaking in literature. Thus, Fuller, like Shelly, uses mythology and transforms and recreates it for poetic ends-and most importantly for Fuller, for feminist ends that aspire to enhance and honor women's attributes and roles which, in turn, effect progressive changes and meaningful improvements.

Furthermore, Fuller," to dramatize "the metamorphosis of suffering into insight" by putting emphasis on mourning and pain as the female counterpart to male depression and this echoes Emerson's belief of "Compensation". Male writers were traditionally granted "the most privileged access to the display of loss". Representations of female suffering, for example, discourses of female mourning, did not reach the status of male grief. In contrast with them, in her poetry, Fuller begins to give the term "a proto-feminist" reconsideration of mourning. "She represents the personal deprivation arising from female's existence within patriarchal culture", while simultaneously constructing personae capable of escaping from area of loss (Steele, "Margaret" 165).

\section{CONCLUSION}

One of the earlier feminists is Margaret Fuller who boldly defies her masculinized society and advocates for woman's rights and their emancipation from the bounds of man in her writings, in prose and poetry.

Fuller's early poetry, can be read from a cultural feminist perspective since Fuller focuses on female traits as powerful entity in leading a female utopian community, making use of the Emersonian tenet of self-reliance but with a new modified version, a feminine one. Fuller concentrates on the difference between male and female, producing her own literature in which it can be labeled as gynocriticism. In her poems to Anna Barker, Fuller is a utopian who seeks idealism in her female friendship, especially, in connection to nature, presenting a vision of matriarchy and confirming superior female values.

Fuller's early poems deal with an innovative version and style based on some traditional mythology, principles of "The cult of True Womanhood" (in relation to flowers imagery and language) and principles of Transcendentalism, especially that of self-reliance, within autobiographical context. Her poems show a special interest in women's roles in family and society as well. Fuller's aim is to highlight women's nature and ability as autonomous individuals who have distinctive female skills that enable them to create and conduct positive effects in the family and society.

The basic feminist principles of Fuller's feminist manifesto Woman in the nineteenth Century are formed by virtue of her early poetry. That is, Fuller's early poems present a nascent feminist thought that pave the way for a contribution in feminism.

\section{WORKS CITED}

Ellison, Julie. Delicate Subjects: Romanticism, Gender, and the Ethics of Understanding. Ithaca: Cornell UP, 1990. Print.

Fuller, Margaret. Woman in the Nineteenth Century. New York: Norton, 1971. Print.

Higginson, T. W. Margaret Fuller Ossoli. New York: Haskell House, 1968. Print.

Maas, Christel-Maria. Margaret Fullers transnationales Projekt: Selbstbildung, feminine Kultur und amerikanische Nationalliteratur nach deutschem Vorbild. [Margaret Fuller's Transnational Project: Selfeducation, Feminine Culture and American National Literature Based on the German Model]. Gottingen: U of Gottingen, 2006. Print.

Mehren, Joan von. Minerva and the Muse: A Life of Margaret Fuller. Amherst: UMP, 1994. Print. 
Marshall, Megan. Margaret Fuller: A New American Life. Boston: Houghton Mifflin Harcourt, 2013. Print.

Marino, Elizabetta. "Powerful Emblems of Protest: Flower Language and Flower Imagery in the Writings of Margaret Fuller". Rome: U of Rome, 2018. PDF file.

Kopcik-Rhyner, Corinne. Flowers of Rhetoric: The Evolving Use of the Language of Flowers in Margaret Fuller's Dial Sketches and Poetry, Elizabeth Stoddard's The Morgesons, Edith Wharton's Summer, Mary Austin's Santa Lucia and Cactus Thorn, and Susan Glaspell's. Diss. Georgia State University. TheVerge, Spring 2012, Web.

Richardson, Robert. "Margaret Fuller and Myth". Prospect, vol. 4, Oct 1979, 169-84. 30 July 2009.

Steele, Jeffery. Transfiguring America: Myth, Ideology, and Mourning in Margaret Fuller's Writing. Columbia: U of Missouri P, 2001. Print.

... "Freeing the Prisoned Queen": The Development of Margaret Fuller's Poetry". Studies in American Renaissance. 1992, 137-75. Print.

... "Margaret Fuller". Encyclopedia of American Poetry: The Nineteenth Century. Ed. Haralson, Eric L. New York: Routledge, 2001. Print.

..., ed. The Essential Margaret Fuller. New Jersey: Rutgars, 1992. Print.

Walters, Barbra. "Cult of True Womanhood: 18201860". American Quarterly, vol. 18, no. 2, Summer 1966, 151-74. Print.

Wayne, K.Tiffany. Encyclopedia of American Transcendentalism. New York: Infabso, 2006. Print.

... Women Thinking: Feminism and Transcendentalism in Nineteenth-Century America. Lanham: Lexington Books, 2005. Print. 